\title{
Innate Immune Response in Implant-Associated Infections: Neutrophils against Biofilms
}

\author{
Ulrike Dapunt $^{1, *}$, Gertrud Maria Hänsch ${ }^{2}$ and Carla Renata Arciola ${ }^{3,4}$ \\ 1 Center for Orthopaedics, Trauma Surgery and Spinal Cord Injury, Heidelberg University Hospital, \\ Schlierbacher Landstrasse 200a, Heidelberg 69118, Germany \\ 2 Institute for Immunology, Heidelberg University, Im Neuenheimer Feld 305, Heidelberg 69120, Germany; \\ maria.haensch@urz.uni-heidelberg.de \\ 3 Research Unit on Implant Infections, Rizzoli Orthopaedic Institute, Bologna 40136, Italy; \\ carlarenata.arciola@ior.it \\ 4 Department of Experimental, Diagnostic and Specialty Medicine, University of Bologna, Bologna 40126, Italy \\ * Correspondence: Ulrike.Dapunt@med.uni-heidelberg.de; Tel.: +49-6221-56-35561; Fax: +49-6221-56-27307 \\ Academic Editor: Jaroslaw W. Drelich \\ Received: 20 February 2016; Accepted: 6 May 2016; Published: 18 May 2016
}

\begin{abstract}
Biofilm has been recognized as a well-protected form of living for bacteria, contributing to bacterial pathogenicity, particularly for opportunistic species. Biofilm-associated infections are marked by their persistence. Extensive research has been devoted to the formation and composition of biofilms. The immune response against biofilms remains rather unexplored, but there is the notion that bacteria within a biofilm are protected from host defences. Here we glance at the mechanisms by which neutrophils recognize and face biofilms in implant infections and discuss the implications of this interplay, as well as speculate on its significance.
\end{abstract}

Keywords: implant infections; biofilm; innate immune response; neutrophils; GroEL; Staphylococcus; orthopedics

\section{Introduction}

Even though major improvements have been made over the last years, bacterial infections of implants are still a feared complication in the field of orthopaedics [1,2]. These infections are particularly difficult to diagnose and frequently require prolonged treatments [3,4], because bacteria are capable of forming sessile communities on the implant surface and embed themselves in a slimy matrix (extracellular polymeric substance), the so-called "biofilm" [5].

Owing to the outstanding work by Bill Costerton and other renowned scientists, we now know that biofilm formation is a trendy lifestyle for bacteria and a well-functioning tool by which opportunistic bacteria acquire pathogenic potential [6-11]. Biofilm formation has also been described in other environments (first, for water-dwelling bacteria adhering on the rocks) and usually helps surviving in disadvantageous conditions, such as lack of nutrition [12-15]. In the human body, however, biofilm formation is thought to play a different role, namely protection against the host's defence mechanisms. Some biofilms are well tolerated by the immune system (such as mucosal biofilms, for example) [16], whereas in other settings, like in the case of artificial joint replacement in orthopaedics, bacterial biofilms are thought to be the main reason for persistent and highly destructive infections [17-20], whose etiologic agents are prevalently Gram-positive species belonging to the Staphylococcus genus, among which particularly Staphylococcus aureus and Staphylococcus epidermidis [19-21].

Furthermore, these infections lead to a loss of bone substance, which results in loosening of the implant and hence the need to perform implant replacement surgery. This procedure often 
leads to debilitating results, and elicits psychological stress in affected patients, as well as high socioeconomic costs due to the protracted medical and surgical treatments [20-24]. Due to these detrimental effects, and because an ever increasing number of prostheses is implanted every year, research in this particular field is considered highly important. Furthermore, since most patients with implant infections unfortunately require surgery, the infection site becomes accessible and tissue samples can be obtained to study the inflammatory process.

\section{Systemic and Local Immune Response in Biofilm Infections}

An association between bacterial infection and bone loss has been well established. However pathomechanisms leading to bone degradation are still unclear [22,23]. Therefore, the aim of our research group during the last couple of years was to evaluate the process linking bone infections with bone loss.

In this context, we studied the systemic and local immune responses in patients suffering from implant infections. Standard systemic markers of an infection, such as elevated C-reactive protein concentration and/or white blood cell count, are known to be frequently unreliable in the case of implant-infections [25,26]. However, we evaluated an activation of T-cells (downregulation of CD28 and upregulation of CD11) in peripheral blood and found that activated T-cells were only in patients with implant infections [27], a rather surprising finding since T-cells are not thought to be chiefly involved in bacterial infections. Accordingly, when evaluating tissue samples from the infected site, we found infiltration of T-cells, as well as enhanced gene expression of CD3 [27].

In the local wound lavage, $\mathrm{T}$ cells were activated, particularly CD8+ cells [28]. Moreover, T cells recovered from the infected site were terminally differentiated and produced interferon gamma, a cytokine known to enhance functions of phagocyte cells, drawing the conclusion that infiltrated $\mathrm{T}$ cells support the local immune defence [29]. Aside from the T-cell response, we mainly looked at polymorphonuclear leukocytes (PMN, neutrophils), since these cells are considered to be the first-line defence against bacterial infections. We found a massive infiltration of activated neutrophils at the infected site, indicated by an upregulation of adhesion proteins (CD11b, CD18), Fc-receptors, MHC class II molecules, or the chemokine receptors CXCR6 [30,31]. Additionally, neutrophils showed an altered functional response, namely an enhanced production of oxygen radicals and a reduced chemotactic activity [32].

Importantly, the number of neutrophils at the infected site correlated with the number of bone-resorbing osteoclasts (Figure 1A,B), which supports the idea that a persistent pro-inflammatory response is generated by immune cells and is doomed to end up with osteoclast generation and bone degradation [33].

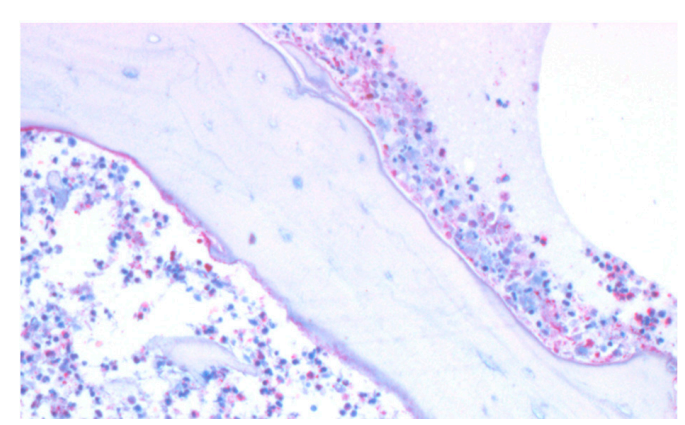

(A)

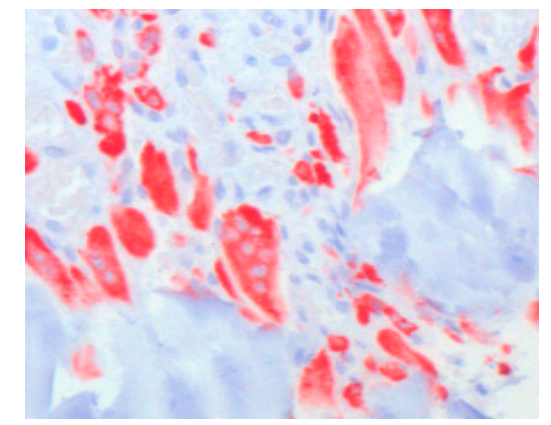

(B)

Figure 1. A dense infiltrate of neutrophils (A) can be detected in bone infections, as well as osteoclasts (B), red, after staining for cathepsin $\mathrm{K}$.

Following this notion further, we evaluated expression of inflammatory cytokines in tissue samples and found that certain cytokines-chiefly CXCL8 (IL-8), CCL3 and CXCL2 (the macrophage inflammatory proteins MIP1 $\alpha$ and MIP2 $\alpha$ ), and S100A9 (MRP14)—were elevated in patients suffering 
from implant infections [34-36]. Since MRP14 is an abundant content in neutrophils, we also investigated MRP14 plasma concentrations and found these to be elevated, advocating MRP14 as a promising future diagnostic marker in peripheral blood [35].

In summary, we are inclined to believe that, contrary to the perception that bacteria embedded in biofilms are not recognized by, and sheltered from, the immune system [37-39], polymorphonuclear leukocytes respond to bacteria in biofilms. Interestingly, it has been shown that most implants are colonized by bacteria without causing symptoms of an infection [40]. Since biofilms represent the preferred lifestyle of bacteria, it is more than likely that neutrophils are faced with developing biofilms. Perhaps biofilm infections are more common than previously presumed and are usually effectively cleared away without us noticing.

\section{How Neutrophils Recognize Biofilms}

Starting from the consideration that the immune system recognizes and responds to biofilms, the next question of interest is "how" biofilms are recognized.

As previously pointed out, biofilm formation is the result of a genetically driven process that is initiated by bacteria attaching to a surface. Once bacteria switch to their biofilm form, they exhibit an altered behavior; for example, acquiring increased resistance towards antibiotics and biocides, and producing an extracellular polymeric substance (EPS) [41]. There are several theories why an increased tolerance to antibiotics might occur, such as conventional resistance mechanisms ( $\beta$-lactamase), but also upregulated efflux pumps, mutations in antibiotic target molecules, and the possibility of a more dormant group of bacteria within the biofilm are thought to contribute [42]. Main constituents of the EPS are the polysaccharide intercellular adhesin (PIA), extracellular-DNA, proteins, and amyloid fibrils [9]. PIA is a poly- $\beta(1-6)-N$-acetylglucosamine (PNAG), partially deacetylated, and positively charged, whose synthesis is controlled by icaADBC locus (reviewed in [43]). Not only the expression of icaADBC is affected by the milieu conditions or subjected to switch on/off mechanisms [44-46], but also there are ica-independent mechanisms of biofilm production that have been detected and described (reviewed in $[47,48]$ ). Indeed, a number of proteins localized in the extracellular matrix of biofilms have been identified that can generate PIA-independent biofilms (reviewed in [48]).The entire process is regulated via the so-called quorum-sensing (QS) molecules (also termed "autoinducers"), which represent a method of bacterial communication [49-51]. Interfering with the QS system is a much debated strategy to combat biofilm-related infections [48-50]. QS molecules and the composition of the EPS are known to be different among bacteria species. The EPS has numerous functions: it serves as a scaffold for the three-dimensional structure of the biofilm, protects the bacteria against environmental stress, facilitates horizontal gene transfers, and sequesters nutrients from the surroundings [52-55].

Generally, invading bacteria are faced with the complex host defence system of different cells, numerous cellular receptors, signalling pathways, and effectors molecules. This abundance of defence mechanisms is required since bacteria species also differ with regard to their susceptibility to the host defence [56-60]. We will focus on polymorphonuclear leukocytes, since these cells can be found in abundance at the infected site, represent the first line of defence against infections and are, therefore, crucial for the host defence against bacteria.

When neutrophils sense a localized infection, they emigrate from blood vessels and migrate actively through the tissue to the site of infection in a well-controlled fashion [59-61]. Once arrived, neutrophils phagocytose bacteria and have a repertoire of cytotoxic substances at their demand to kill bacteria intracellularly or extracellularly, among their reactive oxygen species (ROS) $[62,63]$.

Importantly, neutrophils do not recognize bacteria in an antigen-specific manner. Rather, they are equipped with numerous receptors to recognize evolutionary-conserved surface molecules, the so-called pathogen-associated molecular patterns (PAMPs) and microbe-associated molecular patterns (MAMPs) [64-66].

With regard to free-swimming/"planktonic" bacteria, mechanisms leading to phagocytosis and killing have been thoroughly investigated. Phagocytosis of planktonic bacteria requires a process termed "opsonization", whereby bacteria are coated with an antibody and complement (complement C3b/C3bi). 
Receptors for immunoglobulin G (CD16, CD32 and, following activation, CD64, as well) mediate phagocytosis and intracellular killing together with the complement receptors (CR1, CR3) [56,61,67].

Interestingly, opsonization does not seem to be required for recognition of biofilms (Figure 2) [68] and we, therefore, hypothesized that the slimy substance, the EPS, might contain activating factors; a notion which is also supported by data by others $[69,70]$.

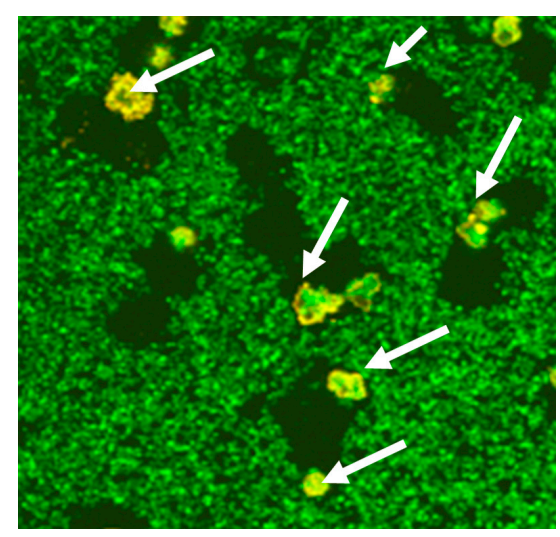

Figure 2. Staphylococcus epidermidis biofilms were grown (green). Neutrophils (arrows) attacked and phagocytosed the biofilm, as seen by the spaces in between the biofilm.

We demonstrated that neutrophils were in fact activated by EPS extracted from Staphylococcus epidermidis biofilms, which was exhibited as release of lactoferrin and upregulation of the activation-associated adherence proteins CD11b/CD18 and of CD66 [71]. Furthermore, we recently investigated potential activating molecules within the EPS in further depth. First, obvious candidates, such as LTA (lipoteichoic acid), PIA (poly- $N$-acetyl(1-6) $\beta$-glucosamine), or LPS as a contaminant, were removed from the EPS. Digestion of the EPS by trypsin resulted in a loss of activation, thus directing our search towards a protein.

We identified the protein GroEL (a bacterial heat shock protein) as an activating factor, since stimulation of neutrophils with recombinant GroEL resulted in an increased oxygen radical production and in an upregulation of the cell surface activation markers CD11b and CD66b (Figure 3A,B) [72]. GroEL is a highly-conserved protein, shares homologies with the human heat shock protein 60 and is essential for protein folding [73]. Of note, it has been shown in the literature that bacteria cannot survive without GroEL [74], indicating this protein as a favorable and strategic target point for neutrophils against various bacteria species. Therefore, GroEL can be regarded as a "pathogen-associated molecular pattern" for the host response. Accordingly, we identified the pattern-recognition receptor TLR4 as a possible receptor for GroEL.

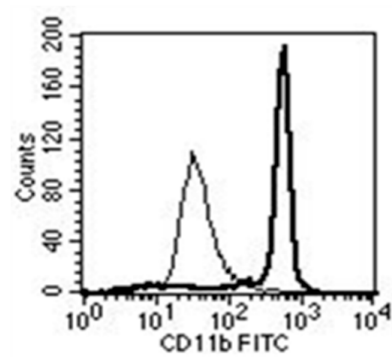

(A)

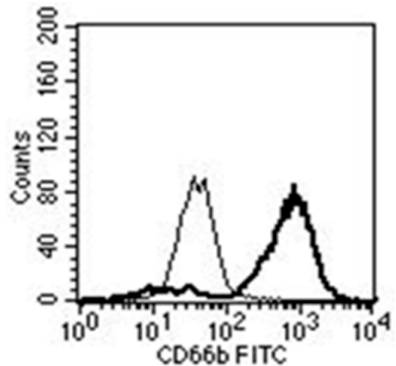

(B)

Figure 3. After stimulation with GroEL, neutrophils upregulated the activation markers CD11b (A) and CD66b (B) as shown by cytofluorometry (thin line: control, thick line: after stimulation with GroEL). 


\section{Neutrophil Extracellular Traps (NETs)}

Another method for neutrophils to fight bacteria is the release of DNA-based traps, also called "netosis" or "NET (neutrophil extracellular traps) formation".

The general idea is that bacteria trapped within the DNA strands are more prone to be killed by neutrophil elastase, cathepsin G, and other bactericidal enzymes contained in NETs [75]. Recently, we were able to demonstrate that EPS and GroEL induce DNA release from neutrophils (Figure 4) [76]. It is unclear whether this release of DNA is an advantage for the host defences, because it has been described in the literature that extracellular DNA actually promotes and strengthens bacterial biofilm formation [55,77-79]. The complex interplay between staphylococcal biofilms and NETs also emerges from the finding that molecules involved in biofilm dispersal, such as nuclease [80], turn out to be capable of mediating the degradation of NETs [81]. Moreover, it should be pointed out that, because biofilms represent an abundant mass of living bacteria, the bacterial metabolic activity would be expected to affect the $\mathrm{pH}$ and oxygen levels of the milieu, reflecting on the immune response and NETs weaving [81].

Therefore, the biological consequence of DNA release in this context is still a matter of debate.

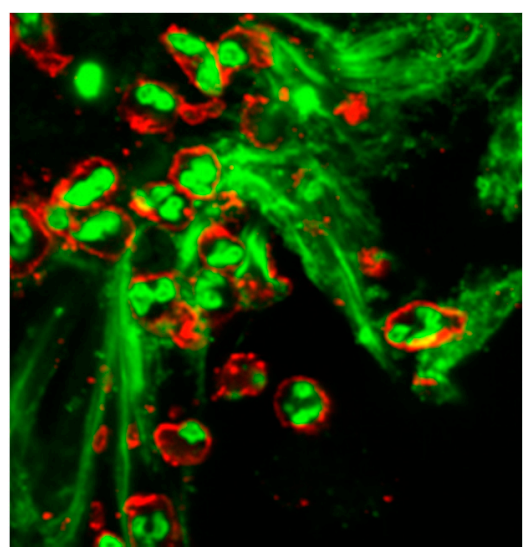

Figure 4. After stimulation with S. epidermidis biofilms, neutrophils also release DNA (stained in green), as shown by laser scan microscopy.

\section{Biomaterials, Biofilms and Neutrophils}

Finally, considering the role and significance of biomaterials in the biofilm-associated infections and the neutrophil-biofilm interaction, we highlight that biomaterials are per se prone to bacterial adhesion and favor biofilm formation [9]. Bacterial adhesion and biofilm production proceed in two steps. First bacterial adhesins mediate the interaction between the bacterium and the extracellular matrix proteins filming the biomaterial surface. Then, adhesin-mediated anchorage allows bacteria to cling to the biomaterial surface and to produce a biofilm. Physical and chemical characteristics of the biomaterial affect bacterial adhesion and biofilm formation. In this context, the development of anti-infective biomaterials and anti-adhesive surfaces have been regarded for a long time as the main strategy to prevent biofilm formation, perfecting more and more their anti-biofilm properties together with their safety for eukaryotic cells [9,82-87]. An interesting approach consists in modifying the surface of materials, which already possess the required bulk properties, making them refractory to bacterial adhesion and to biofilm formation [9,87]. Intrinsically bioactive materials or doped/blended/coated biomaterials with antibacterial substances are being progressively developed and optimized, as the new generation of gently anti-infective biomaterials, i.e., materials that, besides being safe for eukaryotic cells and anti-infective towards bacteria, are also endowed with anti-inflammatory potential or other beneficial biological properties $[88,89]$. For the orthopaedic implants, the anti-infective materials should be designed to be able to oppose bacterial colonization 
and, at the same time, to support tissue repair [9]. Nanotechnologies and nanomaterials are opening new horizons $[9,86]$.

Hänsch et al., studied the behavior of polymorphonuclear neutrophils towards staphylococcal biofilms colonizing orthopaedic implant materials and showed that neutrophils are capable of penetrating biofilms and destroying them, although damaging the host tissues at the site of infection [30,90]. Neutrophils attempt to attack even the copious biofilms that grow onto biomaterials [91].

\section{Conclusions}

In conclusion, it can be reasonably supposed that the neutrophil defence against biofilm infections be effective in the majority of cases. Contrary to the current scientific trend, biofilms are not inherently protected from the host defences.

Neutrophils recognize, attack, and phagocytose biofilms, regardless of "opsonization", which is required for phagocytosis of free-swimming bacteria. Activating molecules within the biofilm matrix, such as the bacterial heat shock protein GroEL, are recognized by neutrophils which are, thus, driven to a number of bactericidal strategies.

However, in the case of chronic biofilm-associated infections, the immune system is not capable of clearing biofilm and eradicating infection in a timely manner, which results in a persistent inflammatory response that leads to tissue damage. It follows that implant biofilm-associated infection tends to become chronic and the damage to endure. In the specific field of an orthopaedic implant-infection, this chronic inflammatory state stimulates a multiplicity of "unwanted side effects", as osteoclast generation, bone degradation and, finally, implant-loosening [92]. However, hope comes from anti-infective biomaterials.

Acknowledgments: A financial contribution by " 5 per mille" grants for Health Research to the Rizzoli Orthopedic Institute of Bologna is acknowledged.

Author Contributions: Ulrike Dapunt, Gertrud Maria Hänsch and Carla Renata Arciola defined the conceptual approach to the scientific subject and planned the lines of its presentation. Ulrike Dapunt performed cytofluorimetric and morphological analyses, with relevant images. Ulrike Dapunt, Gertrud Maria Hänsch and Carla Renata Arciola wrote and edited the manuscript. Carla Renata Arciola revised the final version and all authors approved the final manuscript.

Conflicts of Interest: The authors declare no conflict of interest.

\section{References}

1. Poultsides, L.A.; Liaropoulos, L.L.; Malizos, K.N. The socioeconomic impact of musculoskeletal infections. J. Bone Jt. Surg. Am. 2010, 92. [CrossRef] [PubMed]

2. Haenle, M.; Skripitz, C.; Mittelmeier, W.; Skripitz, R. Economic impact of infected total knee arthroplasty. Sci. World J. 2012, 2012. [CrossRef] [PubMed]

3. Tsukayama, D.T. Pathophysiology of posttraumatic osteomyelitis. Clin. Orthop. Relat. Res. 1999, 360, $22-29$. [CrossRef] [PubMed]

4. Schmidmaier, G.; Lucke, M.; Wildemann, B.; Haas, N.P.; Raschke, M. Prophylaxis and treatment of implant-related infections by antibiotic-coated implants: A review. Injury 2006, 37 (Suppl. 2), S105-S112. [CrossRef] [PubMed]

5. Costerton, J.W.; Stewart, P.S.; Greenberg, E.P. Bacterial biofilms: A common cause of persistent infections. Science 1999, 284, 1318-1322. [CrossRef] [PubMed]

6. Stewart, P.S.; Costerton, J.W. Antibiotic resistance of bacteria in biofilms. Lancet 2001, 358, 135-138. [CrossRef]

7. Costerton, J.W.; Lewandowski, Z.; Caldwell, D.E.; Korber, D.R.; Lappin-Scott, H.M. Microbial biofilms. Annu. Rev. Microbiol. 1995, 49, 711-745. [CrossRef] [PubMed]

8. Parsek, M.R.; Singh, P.K. Bacterial biofilms: An emerging link to disease pathogenesis. Annu. Rev. Microbiol. 2003, 57, 677-701. [CrossRef] [PubMed]

9. Arciola, C.R.; Campoccia, D.; Speziale, P.; Montanaro, L.; Costerton, J.W. Biofilm formation in Staphylococcus implant infections. A review of molecular mechanisms and implications for biofilm-resistant materials. Biomaterials 2012, 33, 5967-5982. [CrossRef] [PubMed] 
10. Hall-Stoodley, L.; Stoodley, P. Evolving concepts in biofilm infections. Cell Microbiol. 2009, 11, $1034-1043$. [CrossRef] [PubMed]

11. Prince, A.S. Biofilms, antimicrobial resistance, and airway infection. N. Engl. J. Med. 2002, 347, 1110-1111. [CrossRef] [PubMed]

12. Flemming, H.C. Biofouling in water systems-Cases, causes and countermeasures. Appl. Microbiol. Biotechnol. 2002, 59, 629-640. [CrossRef] [PubMed]

13. Dunne, W.M., Jr. Bacterial adhesion: Seen any good biofilms lately? Clin. Microbiol. Rev. 2002, 15, $155-166$. [CrossRef] [PubMed]

14. Donlan, R.M.; Costerton, J.W. Biofilms: Survival mechanisms of clinically relevant microorganisms. Clin. Microbiol. Rev. 2002, 15, 167-193. [CrossRef] [PubMed]

15. Johnson, L.R. Microcolony and biofilm formation as a survival strategy for bacteria. J. Theor. Biol. 2008, 251, 24-34. [CrossRef] [PubMed]

16. Macfarlane, S.; Dillon, J.F. Microbial biofilms in the human gastrointestinal tract. J. Appl. Microbiol. 2007, 102, 1187-1196. [CrossRef] [PubMed]

17. Costerton, J.W.; Montanaro, L.; Arciola, C.R. Biofilm in implant infections: Its production and regulation. Int. J. Artif. Organs 2005, 28, 1062-1068. [PubMed]

18. Hall-Stoodley, L.; Costerton, J.W.; Stoodley, P. Bacterial biofilms: From the natural environment to infectious diseases. Nat. Rev. Microbiol. 2004, 2, 95-108. [CrossRef] [PubMed]

19. Arciola, C.R.; An, Y.H.; Campoccia, D.; Donati, M.E.; Montanaro, L. Etiology of implant orthopedic infections: A survey on 1027 clinical isolates. Int. J. Artif. Organs 2005, 28, 1091-1100. [PubMed]

20. Montanaro, L.; Speziale, P.; Campoccia, D.; Ravaioli, S.; Cangini, I.; Pietrocola, G.; Giannini, S.; Arciola, C.R. Scenery of Staphylococcus implant infections in orthopedics. Future Microbiol. 2011, 6, 1329-1349. [CrossRef] [PubMed]

21. Arciola, C.R.; Campoccia, D.; Ehrlich, G.D.; Montanaro, L. Biofilm-based implant infections in orthopaedics. Adv. Exp. Med. Biol. 2015, 830, 29-46. [PubMed]

22. Zimmerli, W.; Trampuz, A.; Ochsner, P.E. Prosthetic-joint infections. N. Engl. J. Med. 2004, 351, $1645-1654$. [CrossRef] [PubMed]

23. Zimmerli, W. Clinical presentation and treatment of orthopaedic implant-associated infection. J. Intern. Med. 2014, 276, 111-119. [CrossRef] [PubMed]

24. Kurtz, S.M.; Lau, E.; Watson, H.; Schmier, J.K.; Parvizi, J. Economic burden of periprosthetic joint infection in the United States. J. Arthroplast. 2012, 27, 61-65. [CrossRef] [PubMed]

25. Esposito, S.; Leone, S. Prosthetic joint infections: Microbiology, diagnosis, management and prevention. Int. J. Antimicrob. Agents 2008, 32, 287-293. [CrossRef] [PubMed]

26. Trampuz, A.; Zimmerli, W. Diagnosis and treatment of infections associated with fracture-fixation devices. Injury 2006, 37 (Suppl. 2), S59-S66. [CrossRef] [PubMed]

27. Dapunt, U.; Giese, T.; Prior, B.; Gaida, M.M.; Hänsch, G.M. Infectious versus non-infectious loosening of implants: Activation of T lymphocytes differentiates between the two entities. Int. Orthop. 2014, 38, 1291-1296. [CrossRef] [PubMed]

28. Wagner, C.; Heck, D.; Lautenschläger, K.; Iking-Konert, C.; Heppert, V.; Wentzensen, A.; Hänsch, G.M. T lymphocytes in implant-associated posttraumatic osteomyelitis: Identification of cytotoxic T effector cells at the site of infection. Shock 2006, 25, 241-246. [CrossRef] [PubMed]

29. Kotsougiani, D.; Pioch, M.; Prior, B.; Heppert, V.; Hänsch, G.M.; Wagner, C. Activation of T Lymphocytes in Response to Persistent Bacterial Infection: Induction of CD11b and of Toll-Like Receptors on T Cells. Int. J. Inflamm. 2010, 2010. [CrossRef] [PubMed]

30. Wagner, C.; Kondella, K.; Bernschneider, T.; Heppert, V.; Wentzensen, A.; Hänsch, G.M. Post-traumatic osteomyelitis: Analysis of inflammatory cells recruited into the site of infection. Shock 2003, 20, 503-510. [CrossRef] [PubMed]

31. Gaida, M.M.; Günther, F.; Wagner, C.; Friess, H.; Giese, N.A.; Schmidt, J.; Hänsch, G.M.; Wente, M.N. Expression of the CXCR6 on polymorphonuclear neutrophils in pancreatic carcinoma and in acute, localized bacterial infections. Clin. Exp. Immunol. 2008, 154, 216-223. [CrossRef] [PubMed]

32. Wagner, C.; Kaksa, A.; Müller, W.; Denefleh, B.; Heppert, V.; Wentzensen, A.; Hänsch, G.M. Polymorphonuclear neutrophils in posttraumatic osteomyelitis: Cells recovered from the inflamed site lack chemotactic activity but generate superoxides. Shock 2004, 22, 108-115. [CrossRef] [PubMed] 
33. Gaida, M.M.; Mayer, B.; Stegmaier, S.; Schirmacher, P.; Wagner, C.; Hänsch, G.M. Polymorphonuclear neutrophils in osteomyelitis: Link to osteoclast generation and bone resorption. Eur. J. Inflamm. 2012, 10, 413-426.

34. Dapunt, U.; Giese, T.; Lasitschka, F.; Lehner, B.; Ewerbeck, V.; Hansch, G.M. Osteoclast Generation and Cytokine Profile at Prosthetic Interfaces: A Study on Tissue of Patients with Aseptic Loosening or Implant-Associated Infections. Eur. J. Inflamm. 2014, 12, 147-159.

35. Dapunt, U.; Giese, T.; Maurer, S.; Stegmaier, S.; Prior, B.; Hänsch, G.M.; Gaida, M.M. Neutrophil-derived MRP-14 is up-regulated in infectious osteomyelitis and stimulates osteoclast generation. J. Leukoc. Biol. 2015, 98, 575-582. [CrossRef] [PubMed]

36. Dapunt, U.; Maurer, S.; Giese, T.; Gaida, M.M.; Hänsch, G.M. The macrophage inflammatory proteins MIP1 $\alpha$ (CCL3) and MIP2 $\alpha$ (CXCL2) in implant-associated osteomyelitis: Linking inflammation to bone degradation. Mediat. Inflamm. 2014, 2014. [CrossRef]

37. Schommer, N.N.; Christner, M.; Hentschke, M.; Ruckdeschel, K.; Aepfelbacher, M.; Rohde, H. Staphylococcus epidermidis uses distinct mechanisms of biofilm formation to interfere with phagocytosis and activation of mouse macrophage-like cells 774A.1. Infect. Immun. 2011, 79, 2267-2276. [CrossRef] [PubMed]

38. Vuong, C.; Voyich, J.M.; Fischer, E.R.; Braughton, K.R.; Whitney, A.R.; DeLeo, F.R.; Otto, M. Polysaccharide intercellular adhesin (PIA) protects Staphylococcus epidermidis against major components of the human innate immune system. Cell Microbiol. 2004, 6, 269-275. [CrossRef] [PubMed]

39. Spiliopoulou, A.I.; Kolonitsiou, F.; Krevvata, M.I.; Leontsinidis, M.; Wilkinson, T.S.; Mack, D.; Anastassiou, E.D. Bacterial adhesion, intracellular survival and cytokine induction upon stimulation of mononuclear cells with planktonic or biofilm phase Staphylococcus epidermidis. FEMS Microbiol. Lett. 2012, 330, 56-65. [CrossRef] [PubMed]

40. Obst, U.; Marten, S.M.; Niessner, C.; Hartwig, E. Bacterial DNA from orthopaedic implants after routine removal. Int. J. Artif. Organs 2011, 34, 856-862. [CrossRef] [PubMed]

41. Donlan, R.M. Role of biofilms in antimicrobial resistance. ASAIO J. 2000, 46, S47-S52. [CrossRef] [PubMed]

42. Høiby, N.; Bjarnsholt, T.; Givskov, M.; Molin, S.; Ciofu, O. Antibiotic resistance of bacterial biofilms. Int. J. Antimicrob. Agents 2010, 35, 322-332. [CrossRef] [PubMed]

43. Arciola, C.R.; Campoccia, D.; Ravaioli, S.; Montanaro, L. Polysaccharide intercellular adhesin in biofilm: Structural and regulatory aspects. Front. Cell. Infect. Microbiol. 2015, 5. [CrossRef] [PubMed]

44. Ziebuhr, W.; Krimmer, V.; Rachid, S.; Lössner, I.; Götz, F.; Hacker, J. A novel mechanism of phase variation of virulence in Staphylococcus epidermidis: Evidence for control of the polysaccharide intercellular adhesin synthesis by alternating insertion and excision of the insertion sequence element IS256. Mol. Microbiol. 1999, 32, 345-356. [CrossRef] [PubMed]

45. Arciola, C.R.; Gamberini, S.; Campoccia, D.; Visai, L.; Speziale, P.; Baldassarri, L.; Montanaro, L. A multiplex PCR method for the detection of all five individual genes of ica locus in Staphylococcus epidermidis. A survey on 400 clinical isolates from prosthesis-associated infections. J. Biomed. Mater. Res. A 2005, 75, 408-413. [CrossRef] [PubMed]

46. Arciola, C.R.; Campoccia, D.; Gamberini, S.; Rizzi, S.; Donati, M.E.; Baldassarri, L.; Montanaro, L. Search for the insertion element IS256 within the ica locus of Staphylococcus epidermidis clinical isolates collected from biomaterial-associated infections. Biomaterials 2004, 25, 4117-4125. [CrossRef] [PubMed]

47. Speziale, P.; Pietrocola, G.; Foster, T.J.; Geoghegan, J.A. Protein-based biofilm matrices in Staphylococci. Front. Cell. Infect. Microbiol. 2014, 4, 171. [CrossRef] [PubMed]

48. Foster, T.J.; Geoghegan, J.A.; Ganesh, V.K.; Höök, M. Adhesion, invasion and evasion: The many functions of the surface proteins of Staphylococcus aureus. Nat. Rev. Microbiol. 2014, 12, 49-62. [CrossRef] [PubMed]

49. Karatan, E.; Watnick, P. Signals, regulatory networks, and materials that build and break bacterial biofilms. Microbiol. Mol. Biol. Rev. 2009, 73, 310-347. [CrossRef] [PubMed]

50. Fuqua, C.; Greenberg, E.P. Listening in on bacteria: Acyl-homoserine lactone signalling. Nat. Rev. Mol. Cell Biol. 2002, 3, 685-695. [CrossRef] [PubMed]

51. Le, K.Y.; Dastgheyb, S.; Ho, T.V.; Otto, M. Molecular determinants of staphylococcal biofilm dispersal and structuring. Front. Cell. Infect. Microbiol. 2014, 4. [CrossRef] [PubMed]

52. Speziale, P.; Geoghegan, J.A. Biofilm formation by staphylococci and streptococci: Structural, functional, and regulatory aspects and implications for pathogenesis. Front. Cell. Infect. Microbiol. 2015, 5. [CrossRef] [PubMed] 
53. Flemming, H.C.; Neu, T.R.; Wozniak, D.J. The EPS matrix: The “house of biofilm cells". J. Bacteriol. 2007, 189, 7945-7947. [CrossRef] [PubMed]

54. Jabbouri, S.; Sadovskaya, I. Characteristics of the biofilm matrix and its role as a possible target for the detection and eradication of Staphylococcus epidermidis associated with medical implant infections. FEMS Immunol. Med. Microbiol. 2010, 59, 280-291. [CrossRef] [PubMed]

55. Whitchurch, C.B.; Tolker-Nielsen, T.; Ragas, P.C.; Mattick, J.S. Extracellular DNA required for bacterial biofilm formation. Science 2002, 295, 1487. [CrossRef] [PubMed]

56. Underhill, D.M.; Ozinsky, A. Phagocytosis of microbes: Complexity in action. Annu. Rev. Immunol. 2002, 20, 825-852. [CrossRef] [PubMed]

57. Stuart, L.M.; Ezekowitz, R.A. Phagocytosis: Elegant complexity. Immunity 2005, 22, 539-550. [CrossRef] [PubMed]

58. Fournier, B.; Philpott, D.J. Recognition of Staphylococcus aureus by the innate immune system. Clin. Microbiol. Rev. 2005, 18, 521-540. [CrossRef] [PubMed]

59. Friedl, P.; Weigelin, B. Interstitial leukocyte migration and immune function. Nat. Immunol. 2008, 9, 960-969. [CrossRef] [PubMed]

60. Wong, C.H.; Heit, B.; Kubes, P. Molecular regulators of leucocyte chemotaxis during inflammation. Cardiovasc. Res. 2010, 86, 183-191. [CrossRef] [PubMed]

61. Witko-Sarsat, V.; Rieu, P.; Descamps-Latscha, B.; Lesavre, P.; Halbwachs-Mecarelli, L. Neutrophils: Molecules, functions and pathophysiological aspects. Lab. Investig. 2000, 80, 617-653. [CrossRef] [PubMed]

62. Borregaard, N. Neutrophils, from marrow to microbes. Immunity 2010, 33, 657-670. [CrossRef] [PubMed]

63. Häger, M.; Cowland, J.B.; Borregaard, N. Neutrophil granules in health and disease. J. Intern. Med. 2010, 268, 25-34. [CrossRef] [PubMed]

64. Ozinsky, A.; Underhill, D.M.; Fontenot, J.D.; Hajjar, A.M.; Smith, K.D.; Wilson, C.B.; Schroeder, L.; Aderem, A. The repertoire for pattern recognition of pathogens by the innate immune system is defined by cooperation between toll-like receptors. Proc. Natl. Acad. Sci. USA 2000, 97, 13766-13771. [CrossRef] [PubMed]

65. Medzhitov, R.; Janeway, C.A., Jr. Decoding the patterns of self and nonself by the innate immune system. Science 2002, 296, 298-300. [CrossRef] [PubMed]

66. Akira, S.; Hemmi, H. Recognition of pathogen-associated molecular patterns by TLR family. Immunol. Lett. 2003, 85, 85-95. [CrossRef]

67. Segal, A.W. How neutrophils kill microbes. Annu. Rev. Immunol. 2005, 23, 197-223. [CrossRef] [PubMed]

68. Stroh, P.; Günther, F.; Meyle, E.; Prior, B.; Wagner, C.; Hänsch, G.M. Host defence against Staphylococcus aureus biofilms by polymorphonuclear neutrophils: Oxygen radical production but not phagocytosis depends on opsonisation with immunoglobulin G. Immunobiology 2011, 216, 351-357. [CrossRef] [PubMed]

69. Gray, E.D.; Peters, G.; Verstegen, M.; Regelmann, W.E. Effect of extracellular slime substance from Staphylococcus epidermidis on the human cellular immune response. Lancet 1984, 1, 365-367. [CrossRef]

70. Johnson, G.M.; Lee, D.A.; Regelmann, W.E.; Gray, E.D.; Peters, G.; Quie, P.G. Interference with granulocyte function by Staphylococcus epidermidis slime. Infect. Immun. 1986, 54, 13-20. [PubMed]

71. Meyle, E.; Brenner-Weiss, G.; Obst, U.; Prior, B.; Hänsch, G.M. Immune defense against S. epidermidis biofilms: Components of the extracellular polymeric substance activate distinct bactericidal mechanisms of phagocytic cells. Int. J. Artif. Organs 2012, 35, 700-712. [CrossRef] [PubMed]

72. Maurer, S.; Fouchard, P.; Meyle, E.; Prior, B.; Hänsch, G.M.; Dapunt, U. Activation of neutrophils by the extracellular polymeric substance of $S$. epidermidis biofilms is mediated by the bacterial heat shock protein GroEL. J. Biotechnol. Biomater. 2015, 5. [CrossRef]

73. Baranova, I.N.; Vishnyakova, T.G.; Bocharov, A.V.; Leelahavanichkul, A.; Kurlander, R.; Chen, Z.; Souza, A.C.; Yuen, P.S.; Star, R.A.; Csako, G.; et al. Class B scavenger receptor types I and II and CD36 mediate bacterial recognition and proinflammatory signaling induced by Escherichia coli, lipopolysaccharide, and cytosolic chaperonin 60. J. Immunol. 2012, 188, 1371-1380. [CrossRef] [PubMed]

74. Young, D.B.; Ivanyi, J.; Cox, J.H.; Lamb, J.R. The $65 \mathrm{kDa}$ antigen of mycobacteria-a common bacterial protein? Immunol. Today 1987, 8, 215-219. [CrossRef]

75. Brinkmann, V.; Zychlinsky, A. Neutrophil extracellular traps: Is immunity the second function of chromatin? J. Cell Biol. 2012, 198, 773-783. [CrossRef] [PubMed] 
76. Dapunt, U.; Gaida, M.M.; Meyle, E.; Prior, B.; Hänsch, G.M. Activation of phagocytic cells by Staphylococcus epidermidis biofilms: Effects of extracellular matrix proteins and the bacterial stress protein GroEL on netosis and MRP-14 release. Pathog. Dis. 2016. in press. [CrossRef] [PubMed]

77. Montanaro, L.; Poggi, A.; Visai, L.; Ravaioli, S.; Campoccia, D.; Speziale, P.; Arciola, C.R. Extracellular DNA in biofilms. Int. J. Artif. Organs 2011, 34, 824-831. [CrossRef] [PubMed]

78. Qin, Z.; Ou, Y.; Yang, L.; Zhu, Y.; Tolker-Nielsen, T.; Molin, S.; Qu, D. Role of autolysin-mediated DNA release in biofilm formation of Staphylococcus epidermidis. Microbiology 2007, 153 Pt 7, 2083-2092. [CrossRef] [PubMed]

79. Kaplan, J.B.; LoVetri, K.; Cardona, S.T.; Madhyastha, S.; Sadovskaya, I.; Jabbouri, S.; Izano, E.A. Recombinant human DNase I decreases biofilm and increases antimicrobial susceptibility in staphylococci. J. Antibiot. (Tokyo) 2012, 65, 73-77. [CrossRef] [PubMed]

80. Mann, E.E.; Rice, K.C.; Boles, B.R.; Endres, J.L.; Ranjit, D.; Chandramohan, L. Modulation of eDNA release and degradation affects Staphylococcus aureus biofilm maturation. PLoS ONE 2009, 4, e5822. [CrossRef] [PubMed]

81. Berends, E.T.; Horswill, A.R.; Haste, N.M.; Monestier, M.; Nizet, V.; Von Kockritz-Blickwede, M. Nuclease expression by Staphylococcus aureus facilitates escape from neutrophil extracellular traps. J. Innate Immun. 2010, 2, 576-586. [CrossRef] [PubMed]

82. Arciola, C.R.; Caramazza, R.; Pizzoferrato, A. In vitro adhesion of Staphylococcus epidermidis on heparin-surface-modified intraocular lenses. J. Cataract Refract. Surg. 1994, 20, 158-161. [CrossRef]

83. Arciola, C.R.; Montanaro, L.; Moroni, A.; Giordano, M.; Pizzoferrato, A. Hydroxyapatite-coated orthopaedic screws as infection resistant materials: In vitro study. Biomaterials 1999, 20, 323-327. [CrossRef]

84. Legeay, G.; Poncin-Epaillard, F.; Arciola, C.R. New surfaces with hydrophilic/hydrophobic characteristics in relation to (no)bioadhesion. Int. J. Artif. Organs 2006, 29, 453-461. [PubMed]

85. Taglietti, A.; Arciola, C.R.; D'Agostino, A.; Dacarro, G.; Montanaro, L.; Campoccia, D.; Cucca, L.; Vercellino, M.; Poggi, A.; Pallavicini, P.; Visai, L. Antibiofilm activity of a monolayer of silver nanoparticles anchored to an amino-silanized glass surface. Biomaterials 2014, 35, 1779-1788. [CrossRef] [PubMed]

86. Campoccia, D.; Montanaro, L.; Arciola, C.R. A review of the clinical implications of anti-infective biomaterials and infection-resistant surfaces. Biomaterials 2013, 34, 8018-8029. [CrossRef] [PubMed]

87. Campoccia, D.; Montanaro, L.; Arciola, C.R. A review of the biomaterials technologies for infection-resistant surfaces. Biomaterials 2013, 34, 8533-8554. [CrossRef] [PubMed]

88. Di Lorenzo, A.; Bloise, N.; Meneghini, S.; Sureda, A.; Tenore, G.C.; Visai, L.; Arciola, C.R.; Daglia, M. Effect of Effect of winemaking on the Composition of Red Wine as a Source of Polyphenols for Anti-Infective Biomaterials. Materials 2016, 9. [CrossRef]

89. Campoccia, D.; Visai, L.; Renò, F.; Cangini, I.; Rizzi, M.; Poggi, A.; Montanaro, L.; Rimondini, L.; Arciola, C.R. Bacterial adhesion to poly-(D,L)lactic acid blended with vitamin E: Toward gentle anti-infective biomaterials. J. Biomed. Mater. Res. A 2015, 103, 1447-1458. [CrossRef] [PubMed]

90. Wagner, C.; Obst, U.; Hänsch, G.M. Implant-associated posttraumatic osteomyelitis: Collateral damage by local host defense? Int. J. Artif. Organs 2005, 28, 1172-1180. [PubMed]

91. Günther, F.; Wabnitz, G.H.; Stroh, P.; Prior, B.; Obst, U.; Samstag, Y.; Wagner, C.; Hänsch, G.M. Host defence against Staphylococcus aureus biofilms infection: Phagocytosis of biofilms by polymorphonuclear neutrophils (PMN). Mol. Immunol. 2009, 46, 1805-1813. [CrossRef] [PubMed]

92. Arciola, C.R. Host defense against implant infection: The ambivalent role of phagocytosis. Int. J. Artif. Organs 2010, 33, 565-567. [PubMed]

(C) 2016 by the authors; licensee MDPI, Basel, Switzerland. This article is an open access article distributed under the terms and conditions of the Creative Commons Attribution (CC-BY) license (http://creativecommons.org/licenses/by/4.0/). 